\title{
A personal memoir*
}

The works of Julio Caro Baroja are both voluminous and varied and it would be presumptious on the part of a disciple to take advantage of this occasion to offer however elogious an appraisal of them, and to do justice to them it would take much more space than I have any right to in such a volumen as this. But there is one, Los Baroja, his familial autobiography, which I feel I might legitimately take as the point of departure for a commentary whose only aim is, as it were, to sketch in an aspect of the background. Some of his readers were surprised by it when it appeared for they had not suspected, despite the highly caustic personal asides to be found in even his most scholarly publications, that he would one day offer them an analysis of himself not only sociological and historical, but introspective and frank. I was not surprised, for twenty years of his friendship had prepared me for it. During the long journeys together by road across the plateaux of Castile or the plains of Andalusia and France I had listened while I drove to the narratives which were to be incorporated within it later and I would like to think that I served, by my occasional comment or question, to draw out details in them. I was perhaps in this embryonic stage, the first "gentle reader" of the book. But there was another reason why my foreknowledge prepared me for it: Julio has always drawn a great deal, not only as a part of his ethnographical work, but for the pleasure of the visual record, and I had observed that among the caricatures which it amused him to draw as well (and which should indeed be regarded as an integral part of his oeuvre for they contain a wealth of observation and comment upon the scenes which he encountered) there was sometimes in the background a sad-looking young bystander with a black moustache and a Basque beret, a witness to the pomp and follies that were depicted, in whom I could recognize the author himself. In somewhat the same spirit Jerome Bosch is believed to have placed his selfportrait, lugubrious and disenchanted,

* Este texto, que constituye uno de los recuerdos más directos y entrañables que se han escrito sobre Julio Caro Baroja, fue publicado por primera vez en el Homenaje a JCB, organizado por Antonio Carreira, Jesús-Antonio Cid y Manuel Gutiérrez Estévez y editado en Madrid por el Centro de Investigaciones Sociológicas en 1978 (pp. 887-893). 
among the crowd which jostles the procession to Calvary. Don Julio has never made a pretense of being the invisible observer and it is not merely a gesture of honesty but a concern for the completeness of his work which prompted him, I feel, to provide in Los Baroja the description of the human being through whom his observations were made. My aim is then to supplement this self-portrait with a vision of some of the periods recounted in the book through the friendly lenses of one whose powers of observation he has done so much to develop.

I first met Julio one cold morning in November 1949, on the farm in the término of Grazalema where I had recently taken up my abode. He arrived with George Foster in what was then called an "haiga" -a slang name of those days for a luxurious American automobile ("lo mejor que haigan)—; my neighbours had never seen anything like it and Julio looked somewhat ill at ease when he had to climb back into it next day to continue the journey. He was doing a cultural survey with the American anthropologist with whom I had at the time only the slightest acquaintance but who had -and what do I not owe to his initiative? - decided to look me up. Both were to become close friends to me. I suppose their visit can only be explained by the fact that we were probably at that moment the only three social or cultural anthropologists working in Spain.

Next summer Julio came back to spend a week with me and his enormous knowledge answered many of the questions that perplexed me. He pointed out what I failed to observe over and over again and it was during one of our long discussions in the evening that I first heard the name of Georg Simmel who was to furnish during the rest of my field work the intellectual framework into which I attempted to cast my data. Apart from our walks to visit other farms in the valley and journeys to neighbouring towns on which he provided a wealth of anecdotes I retain the memory of mornings which he dedicated to what he called dendrolatria - trees being in his view much more worthy of worship than human images. Perhaps for this reason, they were too sacred to him ever to appear in his caricatures - save for an occasional palm-tree in those which illustrate his north African field-work (but perhaps palm-trees were excluded as objects of worship since their simple geometric form and growth negates the essential mystery which arbitrariness gives to branches). The groves of Nemi inspired in him a respect that was notably missing from the representations of village festivals with their porcine beatas, spotty monaguillos, bony priests and burly friars. Dendrolatry consisted of climbing into the crux of an olivetree and there with beret pulled over nose playing some aria from Mozart or Monteverdi upon the xistu, the Basque flute, which stuck out of his pocket like a doctor's stethoscope the rest of the day, in readiness for the 
moment when an act of propitiation might be required. There was nothing Pan-like about this figure whose slow deliberate movements resembled rather the sleepy gymnastics of an affable koalabear.

Julio was never very athletic, and I sometimes worried lest while the xistu occupied both his hands he might not tumble out of his olive-tree to the ground. He never, I think, shared my love of Andalusians, but regarded them rather as privileged subjects of study, because more exaggerated than the peoples of the north of Spain. My enthusiasm for them he viewed rather as an excusable aberration to be explained by being born in a cold climate. Talk of lo tipico to which Andalusians are much given irritated him very much - not surprisingly for an ethnographer perhaps; it soon irritated me- and the pandereta was the symbol of a selfsatisfaction he found it hard to indulge. His health did not allow him to be juerguista, nor his temperament either; the flamboyant side of Andalusia was not for him, but with wry humour he promised that I should be allowed to take him, for his fortieth birthday, to his first bull-fight. Characteristically he knew a great deal about the history of the bull-ring while he had still no intention of ever attending it. I'm glad to say I kept him to his promise and we went to the bulls in Pamplona in 1955 in company with some English cousins of mine who were accustomed to spend the winter fox-hunting and the summer following their favourite bullfighters round Spain. I think that it softened the resentment he harboured against his countrymen for practising such a barbarous festivity to be surrounded by English people. In any case a memorable cartoon depicts the ocasion: the bull has a fifth leg and the public is mainly composed of a blond rubicund breed whom Don Julio identified as "Homo Hemingwayensis".

When I went to Madrid I stayed in the flat of Los Baroja. It was in a rather gloomy late nineteenth century street called Ruiz de Alarcón and it was a flat typical of the period showing a French influence which had become somewhat dusty: a long corridor parquetted in hongroise and in the salon a chandelier with glass pendants. Julio shared the flat with his uncle Pio who was in his eighties and spent most of his day, it seemed to me, in paseo up and down the long corridor, his Basque beret pulled down over his nose, very chapelchiki, and carpet slippers on his feet. As he paraded in this way he muttered repeatedly and with great emotion his opinion of the, then, chief of state: ¡El enano ése, qué tio más asqueroso! Don Pío's features were crinkled up in disgust as he pronounced the word with a shudder.

It must be explained that he himself was exceedingly short in stature and his age had further reduced him, but this fact had not impeded the 
evolution of his ideas towards an excessively simple criterion for the evaluation of men: centimetres. It was indeed as though, having tried all subtler measures, he had finally returned to the simple empiricism of his youth when he practised medecine. Hence in contrast to the "dwarf" who so revolted him he treasured the greatest admiration for General de Gaulle. The rest of humanity was ranked in between "that dwarf" and la grande asperge as the General was nicknamed at St. Cyr. I was fortunate in belonging rather to the latter end of the scale than the former, in fact I was among the only five persons who had ever been to the tertulia and hit his head upon the chandelier on entering. For this reason I enjoyed an enormous prestige in Don Pio's eyes which was totally unmerited on any other grounds. And when argument became animated between the distinguished literary figures of the circle the moment would come when Don Pío raised both his hands for silence and said: «Now let us see what Mr. Pitt-Rivers thinks" as though I were the ultimate arbiter of the Spanish literary scene. From this embarrassing predicament I escaped as best I could, but it was not easy. Don Pío's head was still clear and his speech impecable but he spent much time in the past and was inclined to repeat himsef and not only on the subject of the Chief of State. Yet his conversation at table was of the greatest interest for it cast for me a new light upon his work. It would go something like this: "I have often observed, he would say, that physic cases are inclined towards a hyper exaggeration of the sexual sentiments. It is as though the proximity of death gave special urgency to the attractions of the other sex... As though they felt the need to reproduce before they die. It is said that old fruit-trees which suddenly produce a crop die the following year and perhaps there is some relation in the parallel. I remember a case in Madrid..., and he would start to enumerate the evidence in support of his generalisation until we found ourselves in one that took over from scientific theories and became a fascinating novel in itself. Indeed it was one. We were in the middle of Las noches del buen retiro. Or again: "The nobility of Andalusia have a great capacity for vengeance. It is all the more curious in that they were all raised by English nannies and the English strike me as a people not much given to that sentiment. I don't know whether I'm right, and he looked at me for confirmation. aIt would seem at any rate that it does not come to them from their education, but rather from some inherent disposition" Where were we? In the opening chapter of La feria de los discretos.

I came thus to understand that behind the brisk deadpan ("no comment necessary") style of Don Pío's novels there is always a hidden antropological intention. They are all case-histories summoned in the cause 
of an investigation whose scientific principles are never stated nor even formulated, but which led him in the end to the criterion of centimetres. I became aware also how deeply the medical career on which he had first embarked had marked him. He had soon tired of it and as an intern his superior had told him he would never make a success as a doctor: he wasted too much time talking to the patients about their lives... One sees the novelist already emerging, but in contrast the doctor was never quite effaced. It was he who launched the enquiry in the first place and in accordance with a theory which has recently come into fashion but was undreamed of in medical circles in those days, Don Pío seemed to have grasped that illness is merely the end-product of a blocus, psychic and social quite as much as physiological, a function of the total man. His passionate interest in individuals was not an ultimate end in itself. They were precious to him not because they were unique but because behind their uniqueness lay the answer to the problem of human suffering and indeed of human nature. Behind the novelist stands the doctor and behind the doctor the anthropologist. It is therefore not surprising that his nephew Julio who was so close to him in intelligence and sympathy should have dispensed with the first two and take immediately to our science.

Thanks to Julio I was also privileged to know his other uncle Ricardo, the painter. He lived in the family house in Vera de Bidasoa, called Itzea, not far from Irun. It was a huge cube of a house, very ancient and Basque in style with rather small windows disposed not quite regularly over its façades, and its ground floor consisted of a hall-way into which the coaches formerly drove and were sheltered. In all this it resembled the farm-houses surrounding it though it had never been a farm, and like them it bore a coat of arms over the entrance. Upstairs it smelled of waxed floors and precious ancient home-spun linen, washed in the stream which ran under the windows. The upper floors contained, apart from the living quarters, the library of Don Pío and the studio of Don Ricardo. He was the contrary of his brother in every way. Tall and so well built that age had not bent him, he was the merriest old man I have ever met. He seemed to find the world as funny as his brother found it sad and one might have thought, had one only listened to his stories and never seen his painting, that he had got through life without a moment of sadness or boredom. His painting was the reverse of the image which he showed to the world. The early etchings which first established his reputation are lugubrious in the extreme: huge stones and frail humans mainly in shadow. The decade before the civil war - the finest period of his painting - contains some tranquil almost peaceful landscapes mainly painted in France but some of 
the best are of solitary coaches on windswept roads and ill-lit interiors of his family in moments of depression: Julio swatting over his books, his mother reading. Shortly before the war Don Ricardo lost an eye in an accident and his self-portrait of the following year is the most mournful picture ever painted: the blacked-out lens which hides his blind eye is the most joyful detail in it and the other which stares resolutely out, wide in surprise, seems to envy its blindness. The Civil War left him in economic straits and he took to painting for money at a time when people were buying little but bread. When I met him first he had built up a certain clientèle mainly among the war-time wealthy of San Sebastián. He was too frail to go out much and he painted from memory and imagination. As he advanced in age his focal point of vision lowered and the period receded into the past. Scenes of Basque villages, funerary or festive processions seen from hip-height, showed ladies with muffs and fur hats and gentlemen in toppers. towering against the sky, a sky white with approaching storm. Windows are shuttered. Doors are always closed.

"I can do them very fast now" said Don, Ricardo, "one in the morning, one in the afternoon I sell them for such and such a price -in real values it was about two percent of what they sell for these days in Madrid-. Paint is terribly expensive, but you don't need to put on all that much. I put on half as much as I used to. The picture's just as good..." and he launched into a rakish anecdote which ended in a cascade of laughter.

Julio and I went together to England in the winter of 1952. In Oxford Evans-Pritchard was the head of the department of anthropology and Julio's relationship with him is described in Los Baroja which also gives an account of his experiences in Oxford colleges. Their anachronistic aspect appealed no doubt to his historical sense and the seriousness of the scholarship of the Fellows earned his respect, while at the same time the wealth of their idiosyncrasies amused him. In brief, Oxford was a perfect subject for his caricatural talent and it inspired some of his best drawings, but the account of it in his book is all too brief. One of the anthropologists whom he talked most was Franz Steiner who happened to be my supervisor at the time. He was hardly a typical Oxford figure. He had come to England at the beginning of the war leaving behind a history as tragic as any Czech refugee and thanks to Evans-Pritchard's discernment he had become a member of the staff of the Institute of Social Anthropology. He was a man of inmense learning, but his spoken English was almost incomprehensible. His courage was as great as his learning and his health as poor as his English. When he gave his first lecture in Oxford he asked me, as a friend, to tell him if there were any words he pronunced incor- 
rectly and knowing his sensitivity I did not attempt to be exhaustive. But I felt in duty bound to take him up on one point. His lecture concerned systems of inheritance and every time he came to the word "heir", he pronounced it "hire" so that most of the students thought he was talking about the temporary alienation of goods rather than permanent succession to them. After the lecture he asked me whether it had been all right and I said: "Yes, indeed! It was a brilliant analysis, but there was just one thing..." and I explained that "heir" was pronounced like "air. Franz looked at me searchingly, his eyes flicking from side to side as if he were reading a book -it was a nervous reflex of his- and he said nothing more. But next week when he came to the word again in his second lecture he said with great firmness "hire" and this time everybody understood perfectly because I had explained to them all what his lecture had been about the previous week. Franz and Julio had many long conversations together from which I learned a great deal. "Ese talmudista sabe mucho" said Julio in appreciation. He arranged for Franz to spend his holiday in Galicia and this discovery of Spain so enchanted him that he returned next summer to Andalusia when I was finishing my thesis. After three weeks in Cádiz he came to visit me in Grazalema, bronzed and happy. I had never seen him so healthy before. But a few months later his heart gave out and he died.

That spring was very beautiful in England and I still remember the golden green light of the countryside as we drove across Salisbury Plain returning from Dorset. The birds were all singing, the lambs all cavorting, the horses all neighing, the cows were all munching, the pubs were all full. The energy of spring infected everybody and everything and moved Julio to do a pair of his best caricatures, which in fact are comic sketches for a much more serious thesis, propounded elsewhere in his work, which might be christened "a nutritional theory of culture". The first shows a fat John Bull mounted upon an incredibly inflated horse and surrounded by cows and pigs so bloated they can scarcely stand. All is convex and lush. The other shows a lean Castilian peasant walking to work across the yellow meseta followed by a few scraggy goats. All is concave. The first drawing is entitled "Triunfo de la proteina" and the second, "Miseria del almidón.

Don Julio is famous for his pessimism, his satirical wit and the courtesy of his manners. One of his colleagues once described him as "gentleness itself $f_{n}$ and fortunately was not present the next day when his theories were being analysed by Julio. But at any rate he presents the image of an imperturbable sage, viewing the follies of mankind from a distance that protects his passions from arousal. This is not quite true however. An 
incident in London to the point comes to my mind. We were returning from the country by car, a very small car indeed, an Austin Seven which was the precursor of the Mini of today. He was deploring the state of Spain in general and the condition of the University in particular. The students learned nothing because the teaching was not seriously done. In the cause of modernity properly prepared lectures were giving place to the teachers' prejudices aired in chatty fashion by young men who, before attempting to teach, would have done better to learn something themselves. Julio grew red in the face with anger and the Austin Seven appeared to be too constricted to contain his gestures. It had even been reported to him that a young teacher had declared en chaire that Kant was a majadero. Julio began to answer this young man. We were approaching Marble Arch where a British Bobby in his típico helmet was rocking upon his heels sniffig the summer breeze. In front of him there suddlenly drew up an Austin Sever with a very furious passenger who pointed out of the window at him in denunciatory fashion and bellowed: "No, señor! $\mathrm{El} \mathrm{ma-}$ jadero no era Kant. Es usted. Luckily the policeman understood no Spanish and, knowing how excitable foreigners are, mastered his astonishment and decided to make no retort. The traffic lights changed and we advanced into the traffic jam leaving the Bobby behind. To my relief a abreach of the peace " had been avoided. But I have often wondered how the conversation would have gone, had I been called upon to explain to him why he - rather than Kant- was the silly ass.

An incident occurred before we left London which gave me a further insight into his character. In those days it was necessary to get a visa from the consulate in orden to re-enter Spain and Julio remembered this only the afternoon before he was due to return to Madrid. We went round to the consulate and found to our surprise a queue overflowing onto the stairs which moved so slowly that it soon became clear that we should not even have passed into the office by closing-time. In any case they surely would not give the passport back till next day. As a man of action I decided it was up to me to find the solution, and proud of my newlyacquired Andalusian "know-how" I set off to investigate the corridors of power. I soon found the back entrance to the consulate and working forward reached what I reckoned must be the secretaries' office. I put my head round the door and found a pretty girl - from Seville indeed, she was-, sitting at her type-writer. iQué simpática! It was fixed in three minutes: if I would bring Julio round with his passport she would get it stamped and the consul would sign anything you put under his nose. I returned in triumph, but short-lived triumph it was. Julio refused to leave the queue if this was how it was, he would wait his turn, but connive in 
maniobras of this kind, never! So I'm happy to say he stayed another day in London and I learned that there is more involved in the moral problems of Spain than what I thought of as "Andalusian know-how".

\section{JULIAN PITT-RIVERS}

École Pratique des Hautes Études. Paris

Como un añadido personal al libro Los Baroja, el autor escribe aquí sus propios recuerdos cuando en los primeros años 50 veía a Julio Caro Baroja, a su tío Pío y a su otro tío, Ricardo, el pintor. El autor aprendió mucho de estos encuentros. Le llamaba la atención la fortaleza ética de don Julio y lo mucho que sabía de España, teniendo cosas el país que no le gustaban, como las corridas de toros. De don Pío recuerda el espíritu antropológico que latía en sus ideas, lo que es poco conocido. En cuanto a don Ricardo, su alegría y optimismo ante la vida contrastaban con la personalidad de su hermano y su sobrino, y con el contenido de sus propias pinturas.

As a personal supplement to Los Baroja, the author tells recollections of his own when in the early 1950's he would meet with, and learn from, Julio Caro Baroja, his uncle Pío and his other uncle Ricardo, the painter. He appreciated Caro Baroja's moral fiber and encyclopaedic knowledge of Spain, even though there were many things in the country that Don Julio did not like, like bullfighting. The author was also curious about Don Pío's ideas - which revealed a little-known anthropological spirit-, and was amazed at Don Ricardo's lightheartedness and optimism, so foreign to Don Pío and Don Julio and so contrary to the contents of his paintings. 